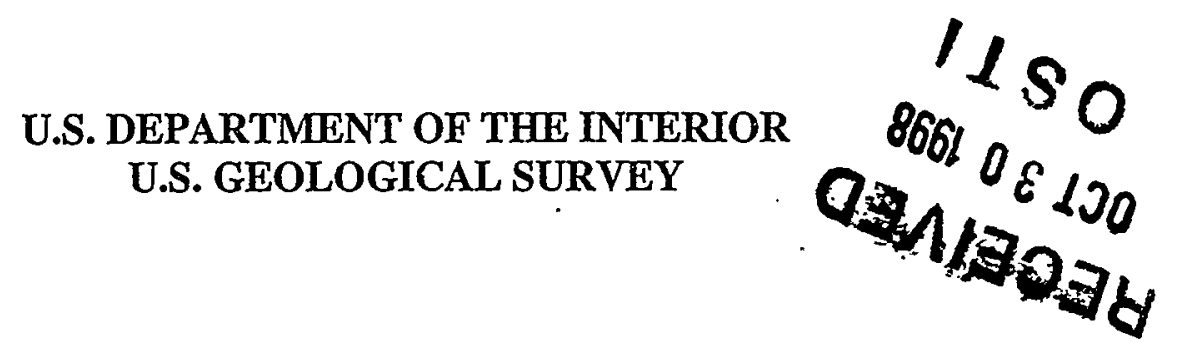

\title{
SUB-CROP GEOLOGIC MAP OF PRE-TERTIARY ROCKS IN THE YUCCA FLAT AND NORTHERN FRENCHMAN FLAT AREAS, NEVADA TEST SITE, SOUTHERN NEVADA

$$
\text { USGS/OFR- }-97-678
$$

By

\author{
James C. Cole', Anita G. Harris ${ }^{2}$, and Ronald R. Wahl ${ }^{1}$ \\ Open-File Report 97-678
}

Prepared in cooperation with the

Nevada Operations Office

U.S. Department of Energy

(Interagency Agreement DE-AI08-96NV11967)

\author{
1997 \\ ${ }^{1}$ U.S. Geological Survey, Mail Stop 913, Federal Center, Denver CO 80225-0046 \\ ${ }^{2}$ U.S. Geological Survey, Mail Stop 926A, National Center, Reston VA 20192 \\ This report is preliminary and has not been reviewed \\ for conformity with U.S. Geological Survey editorial \\ standards and stratigraphic nomenclature. Company \\ names are for descriptive purposes only and do not \\ constitute endorsement by the U.S. Geological Survey
}




\section{DISCLAIMER}

This report was prepared as an account of work sponsored by an agency of the United States Government. Neither the United States Government nor any agency thereof, nor any of their employees, make any warranty, express or implied, or assumes any legal liability or responsibility for the accuracy, completeness, or usefulness of any information, apparatus, product, or process disclosed, or represents that its use would not infringe privately owned rights. Reference herein to any specific commercial product, process, or service by trade name, trademark, manufacturer, or otherwise does not necessarily constitute or imply its endorsement, recommendation, or favoring by the United States Government or any agency thereof. The views and opinions of authors expressed herein do not necessarily state or reflect those of the United States Government or any agency thereof. 


\section{DISCLAIMER}

Portions of this document may be illegible in electronic image products. Images are produced from the best available original document. 


\title{
SUB-CROP GEOLOGIC MAP OF PRE-TERTIARY ROCKS IN THE YUCCA FLAT AND NORTHERN FRENCHMAN FLAT AREAS, NEVADA TEST SITE, SOUTHERN NEVADA
}

\author{
By
}

James C. Cole, Anita G. Harris, and Ronald R. Wahl

\section{TABLE OF CONTENTS}

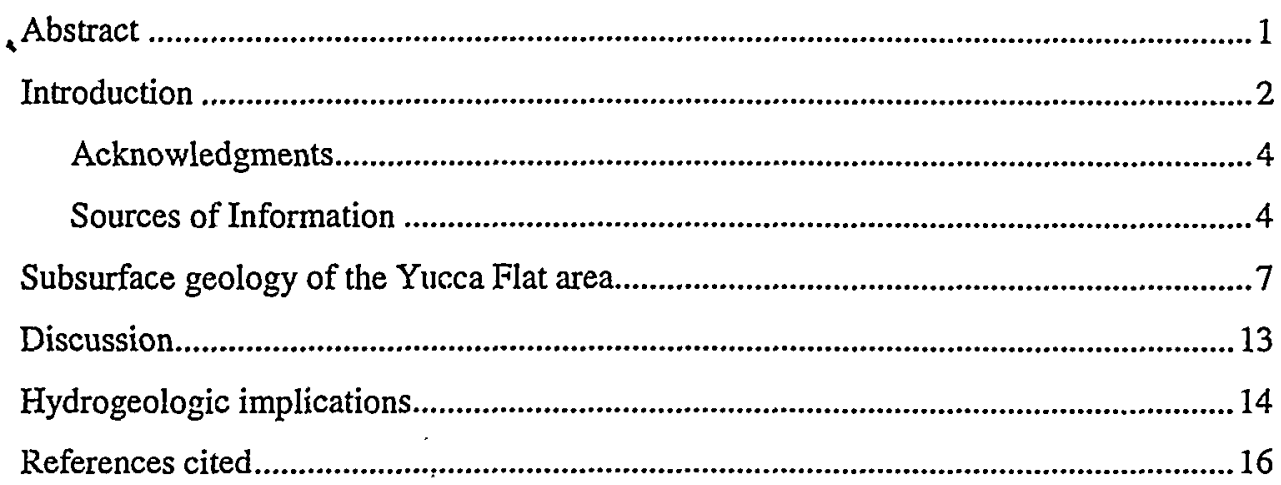

\section{ILLUSTRATIONS}

Figure 1.-- Structural summary map of the major contractional features in pre-Tertiary rocks of the Nevada Test Site region

Figure 2.-- Stratigraphic column for pre-Tertiary rocks in the Nevada Test Site region .5

Figure 3.-- Schematic geologic cross-sections across two transsects in western Yucca Flat.

Plate 1.-- Sub-crop geologic map of pre-Tertiary rocks in the Yucca Flat

- and northern Frenchman Flat areas, Nevada Test Site, southern Nevada .......[in pocket]

\section{TABLES}

Table 1.-- Data for selected drillholes that penetrate pre-Tertiary rock in the Yucca Flat area, Nevada Test Site 20 


\title{
SUB-CROP GEOLOGIC MAP OF PRE-TERTIARY ROCKS IN THE YUCCA FLAT AND NORTHERN FRENCHMAN FLAT AREAS, NEVADA TEST SITE, SOUTHERN NEVADA
}

\begin{abstract}
This map displays interpreted structural and stratigraphic relations among the Paleozoic . and older rocks of the Nevada Test Site.region beneath the Miocene volcanic rocks and younger alluvium in the Yucca Flat and northern Frenchman Flat basins. These interpretations are based on a comprehensive examination and review of data for more than 77 drillholes that penetrated part of the pre-Tertiary basement beneath these post-middle Miocene structural basins. Biostratigraphic data from conodont fossils were newly obtained. for 31 of these holes, and a thorough review of all prior microfossil paleontologic data is incorporated in the analysis. Subsurface relationships are interpreted in light of a revised regional geologic framework synthesized from detailed geologic mapping in the ranges surrounding. Yucca Flat, from comprehensive stratigraphic studies in the region, and from additional detailed field studies on and around the Nevada Test Site.
\end{abstract}

All available data indicate the subsurface geology of Yucca Flat is considerably more complicated than previous interpretations have suggested. The western part of the basin, in particular, is underlain by relics of the eastward-vergent Belted Range thrust system that are folded back toward the west and thrust by local, west-vergent contractional structures of the $\mathrm{CP}$ thrust system. Field evidence from the ranges surrounding the north end of Yucca Flat indicate that two significant strike-slip faults track southward beneath the post-middle Miocene basin fill, but their subsurface traces cannot be closely defined from the available evidence. In contrast, the eastern part of the Yucca Flat basin is interpreted to be underlain by a fairly simple north-trending, broad syncline in the pre-Tertiary units. Far fewer data are available for the northern Frenchman Flat basin, but regional analysis indicates the preTertiary structure there should also be relatively simple and not affected by thrusting.

This new interpretation has implications for ground water flow through pre-Tertiary rocks beneath the Yucca Flat and northern Frenchman Flat areas, and has consequences for ground water modeling and model validation. Our data indicate that the Mississippian Chainman Shale is not a laterally extensive confining unit in the westem part of the basin because it is folded back onto itself by the convergent structures of the Belted Range and CP. thrust systems. Early and Middle Paleozoic limestone and dolomite are present beneath most of both basins and, regardless of structural complications, are interpreted to form a laterally continuous and extensive carbonate aquifer. Structural culmination that marks the French Peak accommodation zone along the topographic divide between the two basins provides a lateral pathway through highly fractured rock between the volcanic aquifers of Yucca Flat and the regional carbonate aquifer. This pathway may accelerate the migration of ground-water contaminants introduced by underground nuclear testing toward discharge areas beyond the Nevada Test Site boundaries. Predictive three-dimensional models of hydrostratigraphic units 
and ground-water flow in the pre-Tertiary rocks of subsurface Yucca Flat are likely to be unrealistic due to the extreme structural complexities. The interpretation of hydrologic and geochemical data obtained from monitoring wells will be difficult to extrapolate through the flow system until more is known about the continuity of hydrostratigraphic units.

\section{INTRODUCTION}

Yucca Flat (fig. 1; pl. 1) is an elongate alluvial basin that shows many characteristics typical of the Basin-and-Range structural and physiographic province in which it lies. It formed consequent to regional crustal extension that was oriented generally east-west between about $9 \mathrm{Ma}$ and the present. This tectonic setting led to the formation of an asymmetric halfgraben structure at the site of Yucca Flat. The overall geometry of the basin was largely controlled by down-to-the-east displacements on the Carpetbag fault system (fig. 1) and westward tilting of Miocene strata (Barnes, Hinrichs, and others, 1963; Cole and others, 1994). Numerous smaller faults formed to accommodate the extension and tilting, all of them trending generally northerly, and most showing down-to-the-east displacement.. Western Yucca Flat, west of the Carpetbag fault system, responded to extensional stresses by forming a more symmetric graben basin and related synthetic faults. Overall subsidence in this western area has been conspicuously less (a few hundred meters maximum) than in the main Yucca Flat basin east of the Carpetbag fault where subsidence locally exceeds 1,300 meters.

Studies of the Yucca Flat and Frenchman Flat basins are significant because these basins were the sites of more than 660 underground nuclear-bomb test detonations on the:Nevada Test Site since the late 1950's (U S. Department of Energy, 1994; Laczniak and others, 1996; testing was suspended in 1995). Although many of these test experiments were conducted in unsaturated rock above the water table, as many as 225 were detonated below the water table or sufficiently close that radioactive byproducts were probably introduced directly into the ground water flow system (Laczniak and others, 1996). Most testing was conducted in the post-miḍdle Miocene alluvial deposits or in underlying rhyolitic volcanic strata deposited between about $16 \mathrm{Ma}$ and $9 \mathrm{Ma}$. Paleozoic sedimentary strata, which underlie both these Tertiary and younger deposits (fig. 2), largely consist of carbonate rock units that make up the principal regional aquifer system in southern Nevada (Winograd and Thordarson, 1975; Laczniak and others, 1996). This aquifer system conveys substantial ground water from central Nevada toward the southwest in the Death.Valley ground water flow system (Winograd and Thordarson, 1975; Dettinger, 1989). Thus, an understanding of the geologic framework of the carbonate aquifer is important to evaluating the potential consequences of: contaminant migration in ground water. 


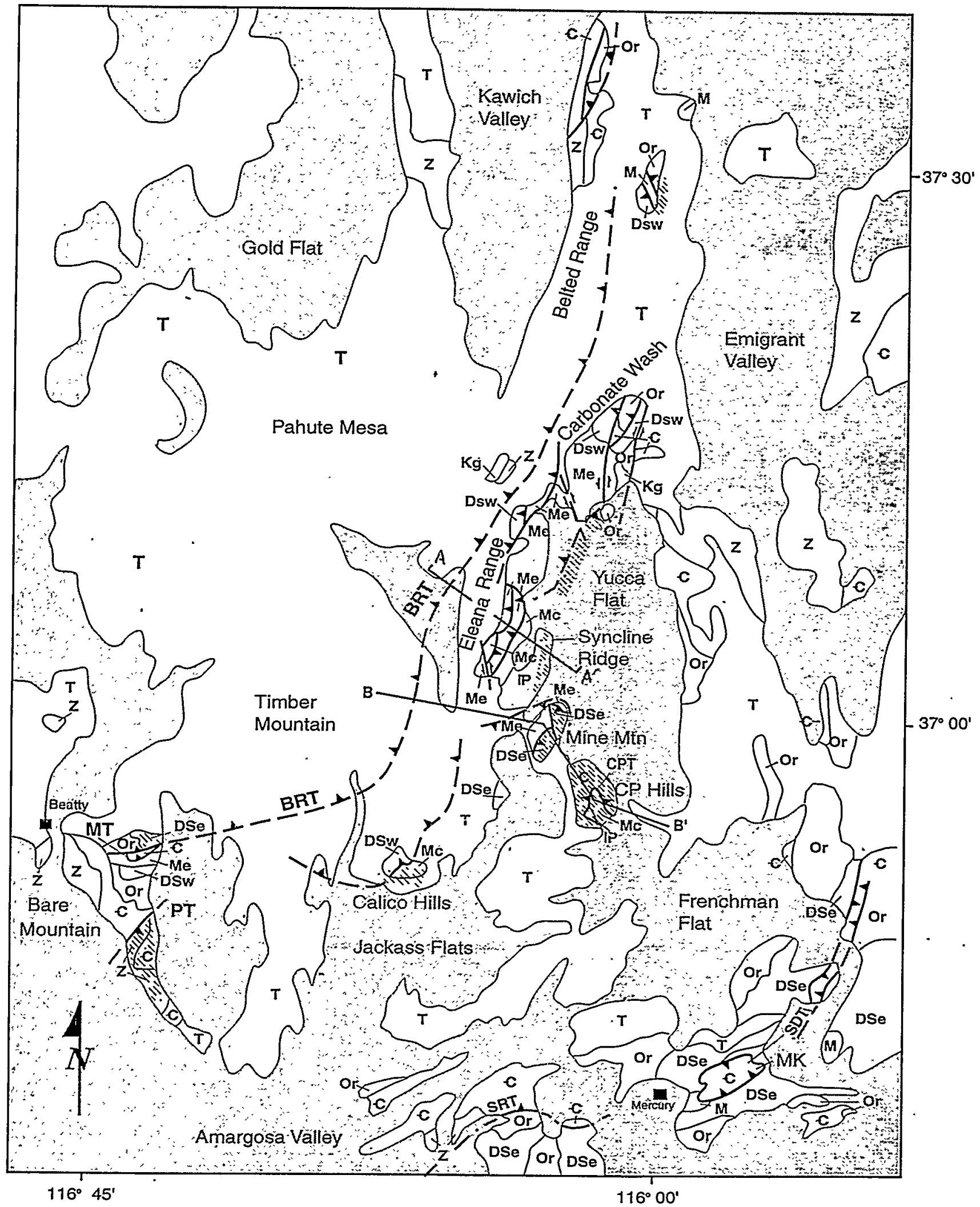

Figure 1.-- Structural summary map of the major contractional features in pre-Tertiary rocks of the Nevada Test Site region. Symbols: shading=Quaternary deposits; $\mathrm{T}=$ Tertiary deposits; $\mathrm{Kg}=$ Cretaceous granite; $\mathrm{IP}=$ Pennsylvanian; $\mathrm{Me}=$ Eleana Formation; $\mathrm{Mc}=$ Chainman Shale; $\mathrm{M}=$ other Mississippian units; $\mathrm{DSe}=$ eastern-facies Devonian-Silurian; DSw=western-facies Devonian-Silurian; Or=Ordovician; $\mathrm{C}=$ Cambrian; $\mathrm{Z}=$ Late Proterozoic; $\mathrm{BRT}=$ Belted Range thrust; FPAZ $=$ French Peak accommodation zone; MT=Meiklejohn thrust; PT=Panama thrust; SDT=Spotted Range thrust; SRT=Specter Range thrust. Diagonal-rule pattern indicates areas of hinterland-vergent deformation attributed to the $C P$ thrust system (see text). 
The U.S. Department of Energy (DOE) initiated the Environmental Restoration Program for the Nevada Test Site in 1989 to evaluate the nature and extent of contamination by radioactive and other hazardous substances resulting from the underground nuclear testing program and other Federal activities at the Site. The long-range goal of this program is to examine alternative strategies for removing, treating, or monitoring contaminants and to take actions to mitigate potential impacts to people and the environment (U.S. DOE, 1991).

Studies described in this report were undertaken by the U.S. Geological Survey in support of the Environmental Restoration Program to assist DOE with geological characterization of these contaminated environments. Our work clarifies the structural and stratigraphic framework of potential pathways that may facilitate the migration of water-borne contaminants from the test areas to points of water discharge or extraction. In particular, the Paleozoic carbonate strata are capable of transporting large quantities of water quickly toward these points of water use (Winograd and Thordarson, 1975; Dettinger, 1989; Laczniak and others, 1996). Knowledge of the structural conditions and stratigraphic relationships within the carbonate aquifer is essential to evaluate risks associated with the manmade contamination resulting from nuclear-weapons testing.

\section{Acknowledgments}

The work described in this report was conducted under interagency agreement DE-AI0896NV11967 between the U.S. Geological Survey and the U.S. Department of Energy, and predecessor agreements.

The authors gratefully acknowledge the assistance provided by the staff of the U.S. Geological Survey Core Library facility in Mercury, Nevada. In particular, Jerry Magner, Ron Martin, Mark Tsatsa, and Dick Hurlbut were indispensable in retrieving samples of drill core and cuttings for numerous wells from the Nevada Test Site, and in assisting with all phases of our investigations.

\section{Sources of Information}

During the last 40 years, more than 200 exploratory holes have been drilled through the alluvial and volcanic deposits of Yucca Flat and into the underlying pre-Tertiary basement rocks. These holes, and numerous shallower borings, were drilled chiefly to obtain engineering, stratigraphic, and structural data to characterize the sites of underground nuclear explosions. The pre-Tertiary rocks were rarely used for nuclear testing (Laczniak and others, 1996), and so many of the exploratory holes only penetrated a few tens of meters below the pre-Tertiary unconformity. Basement samples generally consist only of drill cuttings, supplemented by some bottom-hole core runs. Little systematic work was done under the DOE-sponsored nuclear-weapons testing program to define the stratigraphy and structure of the pre-Tertiary basement because the main program priority was to characterize the test environments. As a consequence, the large number of drill holes in the Yucca Flat basin provide relatively little information about stratigraphic positions, bedding attitudes, or structural conditions of the pre-Tertiary formations penetrated. 


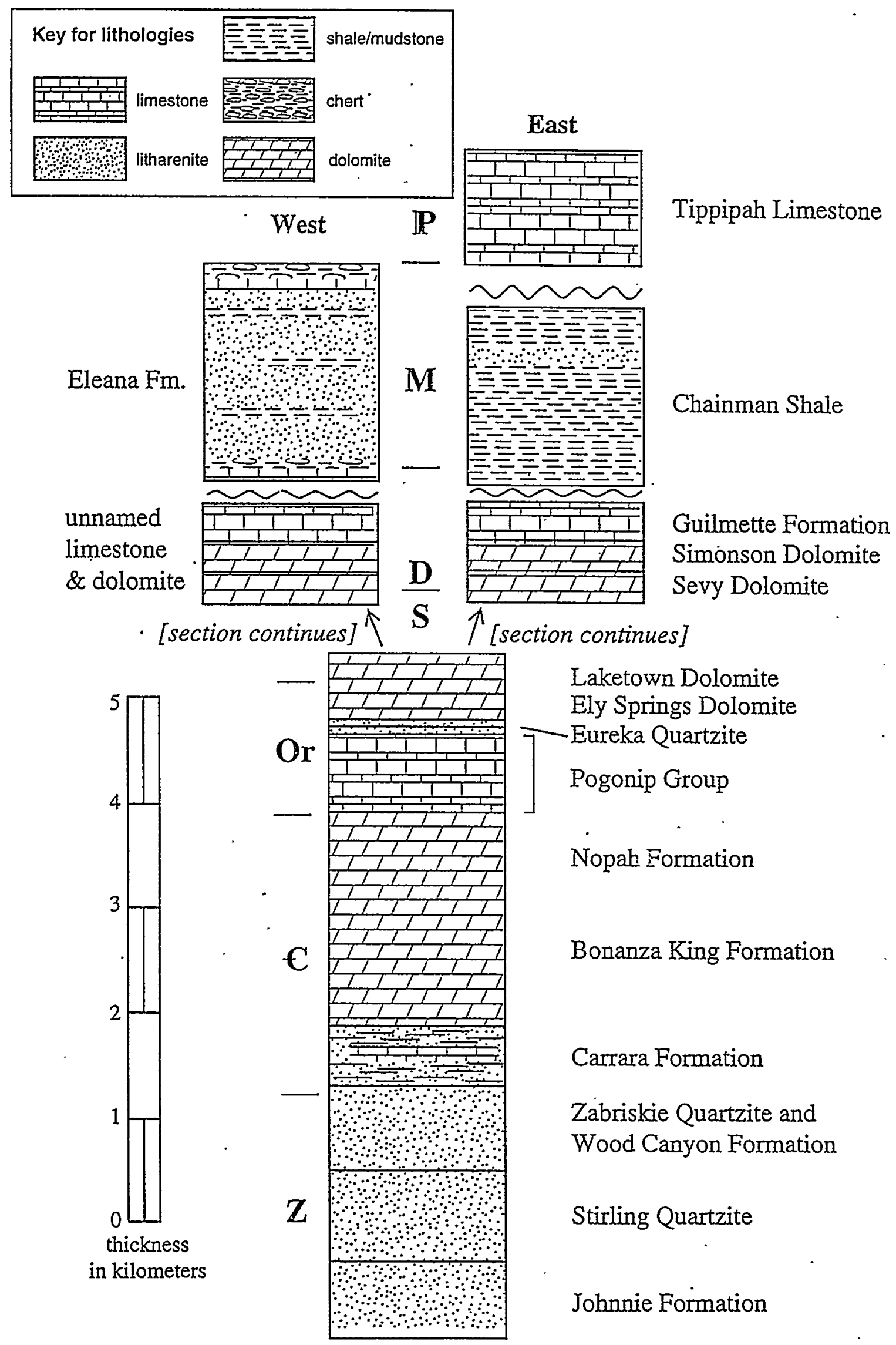

Figure 2.-- Stratigraphic column for pre-Tertiary rocks in the Nevada Test Site region.

Nomenclature and average thickness values shown for Silurian and older units are based on eastern, shallow-water facies; thickness values for Devonian and Mississippian units are variable across the region (see text). 
The sub-crop geologic map in this report (plate 1) is based in large part on substantial new biostratigraphic data obtained through conodont analyses performed by Harris (table 1) on carbonate rocks from exploratory drill holes. Conodont fossil assemblages are diagnostic of time periods from the Middle Cambrian through the Pennsylvanian, but they can provide particularly detailed age control for Ordovician and younger rocks. Many of the samples lacked conodonts but contained common to abundant phosphatic brachiopod fragments in the acid-insoluble residues from the sample processing technique. The phosphatic shell composition is distinct to inarticulate brachiopods that are most abundant in Cambrian rocks, reasonably common in the Ordovician, and scarce in younger strata (Moore and others, 1952). Samples that produced phosphatic brachiopods are indicated on the map (pl. 1) as "Cnb-Or", indicating Nopah Formation, Bonanza King Formation, or Ordovician Pogonip Group (fig, 2). The Nopah and Bonanza King consist largely of thick-bedded dolomite and limestone and are essentially indistinguishable in drill cuttings. Rocks of the Pogonip Group tend to be thinner bedded and more silty than the Cambrian formations, on the whole, but the distinction cannot always be made with confidence from drill cuttings alone.

Clastic rocks that lack fossils can nonetheless be identified from drillhole samples, with varying degrees of certainty. If the drillhole penetrates sufficient stratigraphic section without structural complication, identification is often possible from knowledge of the local sedimentary stratigraphy. Where little sample is available, lithologic characteristics can be diagnostic in some circumstances. For example, detrital muscovite is a reliable indicator of pre-Ordovician strata: Mica is common in the silty parts of the Carrara Formation and all older units, and is usually detectable in the Dunderberg Shale at the base of the Nopah Formation, but it is scarce to absent in younger formations. The Ordovician Eureka Quartzite is usually identifiable by its well sorted, well rounded character and by well developed secondary quartz overgrovyths. Quartzites in the Devonian carbonate units are generally less well sorted and are typically cemented by both calcite and quartz. The Chainman Shale contains some prominent quartzites in its upper part (Scotty Wash Quartzite; Trexler and others, 1996), but they are notably impure, contain detrital tourmaline and zircon, and are not. well sorted. The main body of Chainman Shale is distinguished by its extreme uniformity and thickness, by notably higher organic-carbon content than other shales in the section (Barker, 1994; Trexler and others, 1996), and by thin beds of fine, chert-lithic sand.

The distinction between "western" and "eastern" facies in the Silurian and Devonian rocks pertains to environments of deposition and overall stratigraphic context (Trexler and others, 1996). Evidence for these characteristics is generally not available. from drillhole samples, particularly when only cuttings are available, as bedding and depositional features are obliterated by rotary drilling. The assignment of rocks from a well to one facies or the other on the map (pl. 1) is based on lithologic character, on the regional structural interpretation of thrust components (Cole and Cashman, 1997), and on inferences from nearby holes with better sample material.

The base for plate 1 is a structure-contour map on the top of pre-Tertiary rocks produced by Wahl with Interactive Surface Modeling software (Dynamic Graphics Corp.). This application employs a minimum surface-tension modeling algorithm that is particularly suited to the scattered distribution of data available for this area. The structure-contours are based on interpolations among four types of data, consisting of mapped contacts, topography, drill 
hole data, and geophysical modeling. The modeled surface honors all of the data points and treats data from the various sources with equal weight.

In the ranges surrounding Yucca Flat, elevations for the outcropping Tertiary/pre-Tertiary contacts were digitized from geologic maps. Digital elevation models of the topographic surface (at 1:100,000 scale) were used to constrain the modeled surface as well, in that the modeled surface was required to maintain a lower elevation than topography wherever Tertiary and younger rocks are exposed. Drillhole contact elevations for more than 200 holes were used to define the pre-Tertiary surface beneath central Yucca Flat, and deep drillholes that did not penetrate the pre-Tertiary basement provided conditional control for the maximum surface elevation. In addition, interpretive data from numerous gravity-field measurements obtained over 40 years of exploration of the Yucca Flat basin (Healey and others, 1987) were used to provide detail to the shape of the pre-Tertiary surface. The dense coverage of gravity data had been used historically by Healey and by Wahl to construct detailed 2-dimensional gravity-inversion models of the top of pre-Tertiary rock along east- west traverses, located approximately every 1000 feet north-south across the Yucca Flat basin. These model interpretations provided more than 1000 data points for the locations of steps in the pre-Tertiary surface that are inferred to result largely from post-middle Miocene normal-fault displacements.

The modeled surface of the top of pre-Tertiary rocks in plate 1 is only realistic where it is based on sufficient data, and it becomes increasingly generalized and unrealistic at.the margins of the map. The surface-modeling software calculates the best-fit to all the data and to the constraints imposed by known conditions of surface-maximum and -minimum elevations. The 250 -foot contour interval shown on the map is about as detailed as the data warrant. Most small, isolated, closed-contour loops created by the modeling algorithm: are probably spurious. Similar artificial effects are apparent along the traces of buried fault scarps, which appear to be wavy or corrugated in the model representation, due to the way the minimum-surface-tension algorithm minimizes error among scattered data points. The interpreted fault traces shown in plate 1 are drawn to reflect smoother, more planar fault surfaces in the subsurface, in keeping with the shape of similar fault surfaces known from mapped relationships on the surface.

\section{SUBSURFACE GEOLOGY OF THE YUCCA FLAT AREA}

The pre-Tertiary rocks of the Nevada Test Site region consist of a thick assemblage of siliciclastic and carbonate sedimentary strata that range in age from Late Proterozoic to Early Pennsylvanian. Most of these strata were deposited along the passive western margin of the North American continent up through about Middle Devonian time. This main part of the section includes a lower section of about 10,300 feet $(3,100 \mathrm{~m})$ of quartzite, shale, and quartzose conglomerate (Middle Cambrian and older) and an upper section of about 15,200 feet $(4,600 \mathrm{~m}$ ) of limestone and dolomite (Middle Cambrian to Middle Devonian; fig. 2; Trexler and others, 1996). The Antler orogeny, beginning in Middle Devonian time, resulted from the change to a convergent continental margin that fundamentally altered sedimentation patterns in the region and brought oceanic clastic-source materials into the foreland sedimentary basins. Rocks that were deposited during the Antler event through Mississippian time show strong regional facies variations that reflect shelfal depositional environments 
toward the east and deeper water, slope and submarine-fan depositional environments toward the west (fig. 2; Cole and others, 1994; Trexler and others, 1996; Trexler and Cashman, 1997).

Further convergence in western North America produced regional belts of folding and thrusting, perhaps beginning in Middle Permian time (Snow 1992; Cole and Cashman, 1997). Structures in the Nevada Test Site region related to this convergence (fig. 1) have been shown to profoundly influence the distribution of pre-Tertiary sedimentary units, both laterally and with depth. Detailed discussions of these structures and the evidence for their timing and kinematics are contained in Cole and others (1994) and Cole and Cashman (1997). Details of the Paleozoic stratigraphy and paleogeography are discussed at length in Cashman and Trexler (1994), Trexler and others (1996), and Trexler and Cashman (1997).

This sub-crop geologic map (pl. 1) shows the distribution of pre-Tertiary rock units in the ranges bordering the Yucca Flat and northern Frenchman Flat areas of the Nevada Test Site, and the interpreted distribution of these same units beneath Tertiary and Quaternary deposits that fill these Neogene basins. The interpretation is based on structural and stratigraphic relations within the pre-Tertiary units in the region (Trexler and others, 1996; Cole and Cashman, 1997) and represents the most straightforward extrapolation of these relations beneath the Neogene cover. More complex interpretations cannot be ruled out with available data, but substantially simpler models are also precluded by those same data.

The greatest uncertainties in the interpretation arise from the inherently complex nature of the pre-Tertiary structure in this region (Cole and Cashman, 1997). The Belted Range thrust that passes beneath the Rainier Mesa area emplaced Late Precambrian Wood Canyon Formation generally eastward over Devonian dolomite and the Mississippian Eleana Formation in the direction of the Antler orogenic foreland. Regional considerations suggest that this foreland-vergent thrusting may have been older than Late Permian (Snow, 1992; Cole and Cashman, 1997). The Belted Range footwall consists of numerous duplex horse blocks of Devonian and Mississippian rock displaced eastward relative to underlying footwall blocks (fig. 3). The easternmost of these recognized footwall thrust structures emplaced the Eleana Formation over the time-equivalent Chainman Shale (plate 1; Cashman and Trexler, 1994; Trexler and others, 1996). The fault trace is largely buried but drill hole data indicate it loosely coincides with the break in topographic slope at the eastern foot of the Eleana Range and Quartzite Ridge. For example, drillhole UE-1m at the northeastern corner of the Mine Mountain block penetrated several hundred feet of Eleana section (correlated with the nearby outcrop section) before entering Chainman Shale. Cole and Cashman (1997) interpret this relation to indicate the UE-1m hole was drilled near the leading edge of the Belted Range thrust system. 


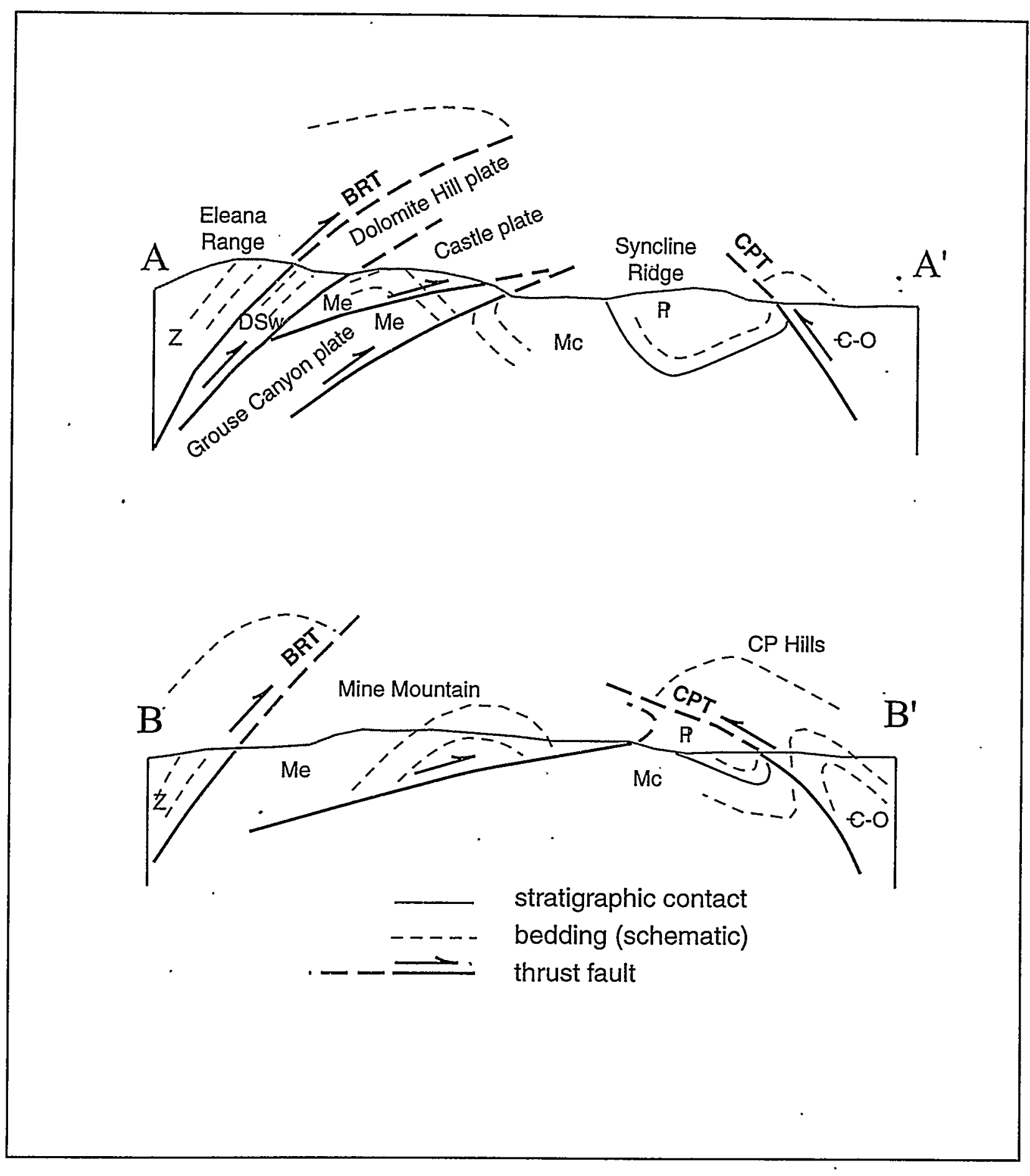

Figure 3.-- Schematic geologic cross-sections along two transsects in western Yucca Flat (after Trexler and others, 1996); minor Cenozoic fault displacements have been ignored. Symbols are defined and lines of section $A-A^{\prime}$ and $B-B^{\prime}$ are shown on figure 1. 
Younger contractional structures related to the CP thrust system are expressed as an irregular band of hinterland-vergent folds and thrusts along the western side of the Yucca Flat basin (fig. 1; Cole and Cashman, 1997). The hangingwall and footwall strata of the CP thrust are interpreted to have belonged to the same regional thrust sheet beneath the Belted Range plate because they contain similar eastern-facies stratigraphic sections (Trexler and others, 1996; Cole and Cashman, 1997). Structures of the CP thrust characteristically show irregular changes in stratigraphic throw along strike and tend to be arcuate or sinuous in plan. Cole and Cashman (1997) attribute the irregularities to local crowding effects around pre-existing Belted Range structures that did not allow the $\mathrm{CP}$ deformation to break cleanly through the section. Correlative structures to the west of Yucca Flat (fig. 1) are known from the Calico Hills and at the Panama thrust in southern Bare Mountain (Carr and Monsen, 1988; Monsen and others, 1992; Cole and Cashman, 1997), where significant changes in stratigraphic throw are apparent along fault traces.

In the CP Hills, Cambrian Zabriskie Quartzite, Carrara Formation, and Bonanza-King Formation are thrust westward and northwestward over Mississippian Chainman Shale and Pennsylvanian Tippipah Limestone in the footwall. The footwall strata are strongly overturned toward the hinterland and locally dip eastward as shallowly as 20 degrees. This overturning relationship was documented in the subsurface through the section penetrated by drillhole ER-6-2 (pl. 1). Paleontologic data from this hole indicate the Bonanza King Formation in the hangingwall of the $\mathrm{CP}$ thrust lies above Devonian Guilmette Formation, which itself is overturned atop the Mississippian Chainman Shale in the footwall (Table 1; Cole and Harris, written commun., 1994; Cole and Cashman, 1997). The GuilmetteChainman contact is well preserved in the drill core, is inclined at about 30 degrees, and is a depositional surface.

Stratigraphic throw on the $\mathrm{CP}$ thrust probably exceeds $5 \mathrm{~km}$ locally in the CP Hills, based on the fault juxtaposition of earliest Cambrian Wood Canyon Formation against

Pennsylvanian Tippipah Limestone (pl. 1; Caskey, 1991; Cole and others, 1994). Toward the north and probably toward the west, the total displacement is dispersed onto multiple faults. For example, in the area between the $\mathrm{CP}$ Hills and Mine Mountain, the entire stratigraphic displacement (Late Cambrian Nopah Formation over Middle-to-Late Mississippian Eleana Formation) is taken up in several thin thrust slices, all of which show overturning and vergence to the northwest and west. From south to north, the structural stacking places upper Bonanza King dolomite over middle Nopah Formation, Nopah Formation over Eureka Quartzite, Eureka and Ely Springs Dolomite over Guilmette Formation, and Guilmette over upper Eleana Formation (fig: 2 ; pl. 1).

Additional evidence of westward overturning of the $\mathrm{CP}$ thrust is displayed farther north at central Mine Mountair. Prominent knobs north and south of the Mine Mountain Road on the east side of this cluster of hills are capped by Upper Devonian Guilmette Formation and Simonson Dolomite that are folded and overturned to the west (Cole and others, 1989; pl. 1) on top of Eleana Formation.

The north end of Syncline Ridge contains very well exposed folds in the Pennsylvanian Tippipah Limestone that are moderately to strongly overturned to the west and (locally) southwest. The hangingwall block that induced this extreme overturning is not preserved in 
outcrop. However, biostratigraphic data for drillhole UE-4ac, located less than one kilometer from the northernmost Tippipah Limestone outcrops, indicate Cambrian or Ordovician strata are in the $\mathrm{CP}$ thrust hangingwall.

North of this location along the eastern front of the central Eleana Range, outcrop evidence of the CP thrust is absent. Drillhole samples from UE-2ce and UE-2u contain phosphatic brachiopod fragments that are consistent with a Middle Ordovician or older age. These Lower Paleozoic strata are interpreted to belong to the leading edge of the westwardvergent $\mathrm{CP}$ thrust hangingwall, which probably lies on top of Eleana Formation at UE-2n (Eleana crops out less than 1,000 $\mathrm{m}$ to the west; pl. 1). Several hundred meters northeast of UE-2ce, drillhole U2cr penetrated Chainman Shale do a depth of about 55 feet. Based on the regional relationships between Chainman Shale and Eleana Formation documented by Trexler and others (1996) and Cole and Cashman (1997), we infer that U2cr penetrated Chainman in the footwall of the $\mathrm{CP}$ thrust. The overlap of the leading edge of the $\mathrm{CP}$ thrust and the inferred leading edge of the Belted Range thrust system (Eleana over Chainman) shown on the map (pl. 1) is consistent with the younger age of the CP structures (Cole and Cashman, 1997), but is certainly oversimplified. Well UE-2ce penetrated nearly 550 feet of dolomite down to elevation 3115 feet, whereas the data for U2cr can only confirm Chainman down to elevation 3237 feet. Post-volcanic faulting inferred from the structure-contour map between the two wells would have positioned the Chainman at an even higher pre-Cenozoic elevation. One likely explanation of these facts is that the $\mathrm{CP}$ thrust is imbricated (as noted between the $\mathrm{CP}$ Hills and Mine Mountain) and that Cambrian dolomite lies both above and beneath the Chainman Shale in this locality.

Data for drillholes in the area of the Baneberry underground nuclear test in northwestern Yucca Flat indicate significant structural complexities (USGS, 1974) that we believe are at least partly manifestations of the CP thrust system. Drillholes U8a-10, U8a-11, and U8a-12 each penetrate brecciated dolomite, Chainman Shale, and terminate in more brecciated dolomite (table 1): Drillholes U8a-4 and UE-8f penetrate Chainman Shale above brecciated dolomite. The dolomites above the Chainman are probably Cambrian or Ordovician based on nearby holes (for example, GH-1, UE-2ab, and Water Well 2). Two samples of dolomite from beneath the Chainman (U8a-4 and U8a-10; table 1) lacked conodonts for biostratigraphic analysis, but are most likely Ordovician or Cambrian as well. These complex relations suggest the $\mathrm{CP}$ thrust system is imbricated here, although extensional normal-fault displacements could also contribute to such complications.

In the area of Smoky Hills, structures believed related to the CP thrust system re-emerge and are exposed at the surface. The Smoky Hills section of Cambrian and Ordovician strata dips west and is overturned westward against Mississippian Eleana Formation. Internal folds in the Nopah Formation also show westward overturning along the east side of the Smoky Hills (Barnes, Houser, and others, 1963). The eastward-vergent Belted Range thrust duplex zone is interpreted to be buried by the CP thrust at this location, based on projections of structure from the Carbonate Wash area to the north (fig. 1; Rogers and Noble, 1969; Cole and Cashman, 1997), but younger structural complications are also indicated. 
Analysis of structural relations here suggest that the Belted Range footwall block is cut by two north-trending strike-slip faults, both of which indicate significant displacements (probably in a sinistral sense; Cole and Cashman, 1997). The Tippinip fault and the Area 13 fault are interpreted to be wrench faults because they cut across thrust-related folds, they place incompatible folds in side-by-side positions, and because of minor structures formed along the Tippinip fault (Cole and others, 1994; Cole and Cashman, 1997). Neither fault can be identified in the subsurface of Yucca Flat on the basis of stratigraphic data. Post-middle Miocene normal faulting on the Carpetbag and Yucca faults (pl. 1), which may partly reactivate the Tippinip and Area 13 faults, respectively, have also offset the pre-Tertiary basement.

In contrast, biostratigraphic data for the eastern side of the Yucca Flat basin, generally east of the Carpetbag fault zone (pl. 1), suggest much simpler geologic conditions. Most drillholes in this area penetrate formations that correspond to the formations exposed along strike to the southeast in the Halfpint Range. Stratigraphic units strike somewhat more west of north than do the faults that break the Halfpint Range and eastern Yucca Flat, and so the exposed formations are progressively younger toward the west and south. Drillhole ER-3-1 penetrated an uncomplicated Middle Cambrian section, and drillhole ER-6-1 penetrated the southwest-dipping section from Silurian lower Sevy Dolomite to the Middle Ordovician Eureka Quartzite'(table 1).

Both drillholes UE-6e and Test Well C penetrated about 100 meters of uniform limestone, quartzose limestone, and dolomitic limestone. Neither sample yielded conodonts for biostratigraphic analysis. The lithology and the negative fossil yield are both consistent with the Middle Devonian Guilmette Formation, a unit that Harris has documented in this area of southern Nevada generally contains sparse conodonts. Previous reports (for example, Barnes, Hinrichs, and others, 1963; Carr, 1974) listed the limestone in Test Well C as Early Cambrian Carrara Formation. We do not believe this interpretation is possible for several reasons. The thick, massive limestone encountered in the well is most unlike the limestones in the Carrara, which are interlayered with conspicuous orange calcareous silt. Moreover, Carrara limestones are commonly oolitic and characteristically contain abundant trilobite debris, phosphatic brachiopod fragments, and detrital muscovite, none of which was present in the acid-insoluble residues of well samples that were processed for conodonts.

The presence of older strata (pre-Middle Devonian) west of UE-6e and Test Well C at UE-1h and UE-1q (table 1) suggests south-central Yucca Flat is underlain by a southeasttrending syncline. Carr (1974) also inferred a synclinal distribution of pre-Tertiary units beneath this part of the basin on the basis of far fewer data. However, the interpretation by Carr (1974) and by Barnes and Poole (1968) that the syncline represented the folded upper plate of the Belted Range thrust (designated by them at the time as the "CP thrust") is inconsistent with the all the data presented in this report.

Trexler and others (1996) and Cole and Cashman (1997) have shown that strata in the hangingwall and footwall of the Belted Range thrust are materially different in their lithologic and sedimentologic characteristics. The hangingwall block is only preserved west of the outcrop band of Chainman Shale. Middle and Lower Paleozoic rocks that are exposed east of the Chainman Shale (or recovered from drillholes east of the Chainman; pl. 1) are similar to 
the eastern-facies strata that make up the Belted Range footwall block. We believe the synclinal fold formed during deformation related to the (redefined) CP thrust as it broke back. westward through this footwall block of the Belted Range thrust (Cole and Cashman, 1997).

\section{DISCUSSION}

The structural and stratigraphic interpretations given above are based on two simplifying assumptions; both of which are known to be untrue to some degree. The main assumption is that extensional normal faulting has not significantly displaced parts of the pre-Tertiary section. Work by Cole and Hudson (Cole and others, 1989; Hudson and Cole, 1993) and by Guth $(1981,1990)$ has shown that some low-angle faults within the pre-Tertiary sections are extensional normal faults. Many of these probably formed as thrusts, or they have displaced blocks from different thrust sheets, but the most recent movement has been in response to extension. Caskey (1991) documented similar structures in the CP Hills (see also Cole and others, 1993, 1994; Cole and Cashman, 1997), and a reconnaissance of the northern Halfpint Range by Cole indicates the mapped faults between the Stirling Quartzite and the Johnnie . Formation are also low-angle extensional faults. Ekren and others (1971), working on the Nellis Air Force Base Gunnery Range north of Yucca Flat (fig. 1), documented that local parts of the Ordovician section had been displaced westward by about 500 to 700 meters prior to Oligocene eruption of the Monotony Tuff. Cole's reconnaissance of this area shows that the Cambrian Dunderberg Shale (A.R. Palmer, written commun., 1995) is displaced westward by as much as $4.5 \mathrm{~km}$ between two extensional fault blocks.

Thus, potential displacements on low-angle normal faults could be quite substantial in the subsurface of the Yucca Flat basin. Geologic relations in northern Yucca Flat that were disclosed as a result of very close-spaced drilling in the area of the Baneberry underground test (near U8a-10; plate 1) suggest such low-angle normal fault complexes may be present in the subsurface (USGS, 1974), as they are known from outcrop nearby (pl. 1). Similarly, the complex sequence of units penetrated by the deep ER-12-1 drillhole (Russell and others, 1996) northwest of Yucca Flat in the Belted Range footwall were interpreted by Cole and others (1993) to indicate extensional complications superimposed on the older thrust structure. However, no attempt has been made to show extensional fault blocks in the subsurface on plate 1 because each of the extensional normal faults noted above is a fairly local structure that cannot be traced over wide lateral extent.

The second qualifying assumption is that the model surface that marks the top of preTertiary rocks was once a fairly smooth, planar feature resulting from erosion prior to volcanism. This surface is inferred to have been subsequently offset by high-angle normal faults during middle to late Neogene subsidence of the modern Yucca Flat basin, and that this faulting is responsible for most of the relief on that surface. The assumption is probably reasonable because most of the faults inferred from gravity data within Yucca Flat have a north-south alignment, equivalent to the trends of similarly young faults exposed in the Halfpint Range to the east.

However, the shape of the pre-Tertiary surface is known to preserve valleys and moderately deep canyons formed by the drainage system that was buried at the onset of volcanic activity (Houser and Poole, 1960; P. FitzMaurice, written commun., 1994). These 
canyons are locally more than 150 meters deep and are especially conspicuous in outcrop in the Eleana Range north of Yucca Flat. The detailed drilling conducted in the vicinity of UE$8 \mathrm{f}$ shows a substantial trough was present when Miocene volcanism began, and that trough accumulated lacustrine sediments with organic-rich beds that formed low-grade coal (USGS, 1974; Barker, 1994). Tertiary clastic sediments are locally thick within these paleovalley settings, and lithologic logs from drillholes in central Yucca Flat near U3cn-5 (for example) indicate many tens of meters of these sediments that suggest considerable paleotopography ( $P$. FitzMaurice, written commun., 1994).

The sub-crop geologic map was drawn with the assumption that all north-trending discontinuities in the contoured surface are buried fault scarps. As the foregoing paragraph demonstrates, this assumption is not necessarily true because substantial paleotopographic relief is locally present. From the point of view of the gravity meter and the modeler of gravity data, fault scarps and paleotopographic escarpments will look the same (Cole and others, 1989). Buried contacts between high-density carbonate rocks and lower density shale or quartzite will also appear similar to a scarp in gravity data. We believe that some of the sinuous trends in "fault scarps" on the contoured surface (for example between UE-4af, UE$4 \mathrm{av}$, and UE-2co) reflect the singular or combined effects of these non-fault-related features.

\section{HYDROGEOLOGIC IMPLICATIONS}

The biostratigraphic and lithologic data compiled from subsurface samples provide compelling evidence for great structural complexity beneath Yucca Flat and northern Frenchman Flat. Block faulting and tilting that accompanied the post-middle Miocene subsidence of the Yuicca Flat basin produced significant displacements of geologic units on numerous faults, and the aggregate structural relief is on the order of $2 \mathrm{~km}$ (Carr and others, 1975; Cole and others, 1994). These block-fault displacements could be accurately modeled in a three-dimensional framework for central Yucca Flat due to the abundant drillhole data available for the Tertiary volcanic units. However, such data are of little aid in modeling the distribution of stratigraphic units in the pre-Tertiary basement because of the complex history that predates the block-fault offsets (Cole and Cashman, 1997).

Explicit three-dimensional block models of pre-Tertiary hydrostratigraphic units could be constructed for subsurface Yucca Flat, but would require significant simplifying assumptions about the distribution and structural conditions of carbonate-aquifer units and confining units. The accuracy of such models would be exceptionally difficult to evaluate because of the high probability of unknown major buried faults and because of the lack of credible evidence to estimate displacements. Simulations of ground-water flow through the Yucca Flat area from such model's would likely reflect these simplifying assumptions more than the actual subsurface conditions. In such situations, predictions or expectations based on the models will be difficult to validate because the flow-path model would be neither unique nor wellbounded. The value of data for water levels, water chemistry, borehole flow surveys, or isotope geochemistry will be limited for testing flow models because of large uncertainties about the hydrostratigraphic units that such data reflect.

Concerns about structural and stratigraphic uncertainties are greatest for the areas in western Yucca Flat, generally west of the Carpetbag fault system. The subsurface evidence 
and the structural style exposed in the hills in this area clearly document the complicating influences of interfering foreland- and hinterland-vergent thrust structures and extensional overprints. Both the Belted Range thrust and the $\mathrm{CP}$ thrust have placed carbonate rocks beside and above the Chainman Shale (fig. 3), the major stratigraphic confining unit in the area. In so doing, the converging thrust systems are interpreted to limit the lateral extent of the Chainman Shale in the subsurface and thereby reduce its regional effect as an inhibitor of ground water flow. We believe the data indicate the Chainman Shale is absent from subsurface Yucca Flat east of the trace of the CP thrust system. For similar reasons, we would not expect Chainman Shale to be present in northern Frenchman Flat or south of a line between the CP Hills and the Calico Hills to the west (fig. 1).

East of the Carpetbag fault system, the available evidence suggests the pre-Tertiary rocks are geologically much simpler. With the exception of the northeasternmost part of the Yucca Flat basin, all drillholes encountered limestone or dolomite belonging to the thick Lower and Middle Paleozoic carbonate section. The age relationships and the structural geometry exposed in the Halfpint Range to the east all support a model of a broad synclinal warp in the pre-Tertiary rocks under central and southern Yucca Flat. This fold may persist to the south, but cannot be projected with confidence into the Frenchman Flat subsurface because data are lacking.

The hydrogeologic effect of this synclinal fold, in any event, is probably secondary to the effect of the French Peak accommodation zone (Hudson, 1997). The accommodation zone structure underlies the topographic divide between Yucca Flat and Frenchman Flat (fig. 1) and is interpreted to project to the east and west for tens of kilometers (Hudson, 1997). The zone is marked by a structural culmination in both Tertiary and pre-Tertiary units that results from extension-related subsidence in the Frenchman Flat basin to the south and in the Yucca Flat basin to the north. Because these basins tilted and extended in opposite directions as they formed (Yucca Flat extended eastward, while Frenchman Flat extended westward), the accommodation zone was the site of extreme local changes in stress that produced curved faults with highly variable displacements (Hudson, 1997). As a result, rocks along the accommodation zone are intensely faulted and fractured, even though they were left standing structurally high and largely unextended (Hudson, 1997).

The French Peak accommodation zone does not appear to act as a barrier to southward flow of ground water in either the regional carbonate aquifer or the volcanic aquifer because water levels in these units are effectively the same to the north and to the south (Laczniak and others, 1996). Because of the structural culmination in the zone, the Tertiary/pre-Tertiary unconformity lies above the potentiometric surface (water table) at about 2400 feet elevation in both the volcanic and carbonate aquifers at Test Well $\mathrm{C}$ and for a considerable distance east and west. The French Peak accommodation zone thus provides a critical pathway of fractured rocks through which ground water can move laterally from the volcanic aquifers into the regional carbonate aquifer, rather than downward as these two aquifers are situated elsewhere in the basin (Winograd and Thordarson, 1975). Ground-water contaminants in the volcanic units that were introduced by underground nuclear testing would be expected to migrate more rapidly once they entered the regional carbonate aquifer (Winograd and Thordarson, 1975). This direct lateral path through the fractured accommodation zone would be expected to expedite that connection (Laczniak and ọthers, 1996). 


\section{REFERENCES CITED}

Barker, C.E., 1994, Thermal and petroleum generation history of the Mississippian Eleana Formation and Tertiary source rocks, Yucca Mountain area, southern Nye County, Nevada: U.S. Geological Survey Open-File Report 94-161, 42 p.

Barnes, Harley, 1962, Stratigraphic interpretation of rocks penetrated by UE-15d drill hole: U.S. Geological Survey Technical Letter Yucca-1, Supplement 5, 8 p.

Barnes, Harley, Hinrichs, E.N., McKeown, F.A., and Orkild, P.P., 1963, U.S. Geological Survey investigations of Yucca Flat, Nevada Test Site, Part A - Geology of the Yucca Flat area: U.S. Geological Survey Technical Letter NTS-45, Part A, 196 p.

Barnes, Harley, Houser, F.N., and Poole, F.G., 1963, Geologic map of the Oak Spring quadrangle, Nye County, Nevada: U.S. Geological Survey Geologic Quadrangle Map GQ-214, scale 1:24,000.

Barnes, Harley, and Poole, F.G., 1968, Regional thrust-fault system in Nevada Test Site and vicinity, in Eckel, E.B., ed., Nevada Test Site: Geological Society of America Memoir 110, p. 233-238.

Carr, M.D., and Monsen, S.A., 1988, A field trip guide to the geology of Bare Mountain, in Weide, D.L., and Faber, M.L., eds., This extended land, geological journeys in the southern Basin and Range: Geological Society of America, Cordilleran Section, Field Trip Guidebook, p. 50-57.

Carr, W.J., 1974, Summary of tectonic and structural evidence for stress orientation at the Nevada Test Site: U.S. Geological Survey Open-File Report 74-176, 53 p.

Carr, W.J., Bath, G.D., Healey, D.L., and Hazelwood R.M., 1975, Geology of northern Frenchman Flat, Nevada Test Site: U.S. Geological Survey Report USGS-474-216 [NTS-188], 24 p.

Carr, W.J., Miller, C.H., and Dodge, H.W., Jr., 1967, Geology, physical properties, and surface effects at the Discus Thrower site, Yucca Flat, Nevada Test Site: U.S. Geological Survey Technical Letter NTS-162, supp. 1,30 p.

Cashman, P.H., and Trexler, J.H., Jr., 1994, The case for two, coeval, Mississippian sections at the Nevada Test Site, in McGill, S.F., and Ross, T.M., eds., Geological Investigations of an Active Margin: Geological Society of America Cordilleran Section guidebook, San Bernardino, California, 1994, p. 76-81.

Caskey, S.J., 1991, Mesozoic and Cenozoic structural geology of the CP Hills, Nevada Test Site, Nye County, Nevada; and regional implications: Reno, University of Nevada, M.S. thesis, 133 p., 3 plates, 1:24,000 scale.

Cole, J.C., 1997, Major structural controls on the distribution of pre-Tertiary rocks, Nevada Test Site vicinity, Nye County, Nevada: U.S. Geological Survey Open-File Report 97-533, scale 1:100,000, 19 p.

Cole, J.C., Wahl, R.R., and Hudson, M.R., 1989, Structural relations within the Paleozoic basement of the Mine Mountain block; implications for interpretations of gravity data in Yucca Flat, Nevada Test Site: Proceedings from Fifth Symposium on Containment of Underground Nuclear Explosions, Santa Barbara, California, Lawrence Livermore National Laboratory, CONF-8909163, vol. 2, p. 431-456.

Cole, J.C., Harris, A.G., Lanphere, M.A., Barker, C.E., and Warren, R.G., 1993, The case for pre-middle Cretaceous extensional faulting in northern Yucca Flat, southwestern Nevada: Geological Society of America Abstracts with Programs, vol. 25, no. 5, p. 22. 
Cole, J.C., Trexler, J.H., Jr., Cashman, P.H., and Hudson, M.R., 1994, Structural and stratigraphic relations of Mississippian rocks at the Nevada Test Site, in McGill, S.F., and Ross, T.M., eds., Geological Investigations of an Active Margin: Geological Society of America Cordilleran Section guidebook, San Bernardino, California, 1994, p. 66-75.

Cole, J.C., and Cashman, P.H., [in press 1998], Structural relationships of the pre-Tertiary rocks of the Nevada Test Site region, southern Nevada: U.S. Geological Survey Professional Paper 1607, 40 proof p.

Dettinger, M.D., 1989, Distribution of carbonate-rock aquifers in southern Nevada and the potential for their development--summary of findings, 1985-88: State of Nevada, Program for the study and testing of carbonate-rock aquifers in eastern and southern Nevada, Summary Report Number 1, 37 p.

Dixon, G.L., Carr, W.J., and Aamodt, P.L., 1973, Lithologic logs and stratigraphic identification of exploratory and emplacement drill holes in Area 4, Nevada Test Site: U.S. Geological Survey Report USGS-474-173 [NTS-249], 33 p.

Dixon, G.L., Quinlivan, W.D., Ray, J.M., and Ohl, J.P., 1975, Supplementary lithologic logs and stratigraphic identification of exploratory and emplacement drill holes in Areas 3, 4, and 7, Nevada Test Site: U.S. Geological Survey Report USGS-474-211 [NTS-260], 83 p.

Dixon, G.L., Sargent, K.A., and Spengler, R..W., 1973, Lithologic logs and stratigraphic identification of exploratory and emplacement drill holes in Area 3, Nevada Test Site: U.S. Geological Survey Report USGS-474-151 [NTS-244], 134 p.

Ekren, E.B., Anderson, R.E., Rogers, C.L., and Noble, D.C., 1971, Geology of the northern Nellis Air Force Base Bombing and Gunnery Range, Nye County, Nevada: U.S. Geological Survey Professional Paper 651, $91 \mathrm{p}$.

Emerick, W.L., 1983, Exploratory drill holes UE-1a, UE-1b, and UE-1c, Yucca Flat: U.S. Geological Survey Report USGS-474-317 [Yucca-54], 11 p.

Fernald, A.T., Byers, F.M., Jr., and Ohl, J.P., 1975, Lithologic logs and stratigraphic identification of exploratory and emplacement drill holes in Areas 1 and 6, Nevada Test Site: U.S. Geological Survey Report USGS474-206 [NTS-256], $58 \mathrm{p}$.

Guth, P.L., 1981, Tertiary extension north of the Las Vegas Valley shear zone, Sheep and Desert Ranges, Clark County, Nevada: Geological Society of America Bulletin, vol. 92, p. 763-771.

Guth, P.L., 1990, Superposed Mesozoic and Cenozoic deformation, Indian Springs quadrangle, southern Nevada, in Wernicke, B.P., ed., Basin and Range extensional tectonics near the latitude of Las Vegas, Nevada: Boulder, Geological Society of America Memoir 176, p. 237-249.

Healey, D.L., Harris, R.N., Ponce, D.A., and Oliver, H.W., 1987, Complete Bouguer gravity map of the Nevada Test Site and vicinity, Nevada: U.S. Geological Survey Open-File Report 87-506, scale 1:100,000.

Houser, F.N., and Poole, F.G., 1960, Structural features of pyroclastic rocks of the Oak Spring Formation at the Nevada Test Site, Nye County, Nevada, as related to the topography of the underlying surface, in Geological Survey Research 1960: U.S. Geological Survey Professional Paper 400-B, p. B266-B268.

Hudson, M.R., 1997, Structural geology of the French Peak accommodation zone, Nevada Test Site, southwestern Nevada: U.S. Geological Survey Open-File Report 97-56, 25 p., scale 1:12,000.

Hudson, M.R., and Cole, J.C., 1993, Kinematics of faulting in the Mine Mountain area of southern Nevada: Evidence for pre-middle Miocene extension: Geological Society of America Abstracts with Programs, vol. 25 , no. 5 , p. 55. 
I.T. Corporation, 1995a, Completion report for Well ER-3-1: I.T. Corporation report DOE/NV-396, 65 p.

I.T. Corporation, 1995b, Completion report for Well ER-19-1: I.T. Corporation report DOE/NV-410, 85 p.

Laczniak, R.J., Cole, J.C., Sawyer, D.A., and Trudeau, D.A., 1996, Summary of hydrogeologic controls on ground-water flow at the Nevada Test Site, Nye County, Nevada: U.S. Geological Survey Water Resources Investigations Report 96-4109, 59 p.

Longwell, C.R., Pampeyan, E.H., Bowyer, Ben, and Roberts, R.J., 1965, Geology and mineral deposits of Clark County, Nevada: Nevada Bureau of Mines and Geology Bulletin 62, 218 p.

Maldonado, Florian, Steele, S.G., and Townsend, D.R., 1979, Supplementary lithologic logs of selected vertical drill holes in Area 12, Nevada Test Site: U.S. Geological Survey Report USGS-474-261, 61 p.

McKague, H.L., 1980, Summary of measured medium properties of Paleozoic rocks at the DOE Nevada Test Site: Lawrence Livermore National Laboratory report UCRL-52884, 9 p.

Miller, D.R., 1970, Lithologic logs and stratigraphic identification for vertical drill holes in Area 12, Nevada Test Site: U.S. Geological Survey Administrative Report Area 12-27, 34 p.

Monsen, S.A., Carr, M.D., Reheis, M.C., and Orkild, P.P., 1992, Geologic map of Bare Mountain, Nye County, Nevada: U.S. Geological Survey Miscellaneous Investigations Map I-2201, scale 1:24,000.

Moore, J.E., 1962, Selected logs and drilling records of wells and test holes drilled at the Nevada Test Site prior to 1960: U.S. Geological Survey Open-File Report [TEI-804], 54 p.

Moore, J.E., Doyle, A.C., Walker, G.E., and Young, R.A., 1963, Ground water test well 2, Nevada Test Site, Nye County, Nevada, with a section on Geophysical logs, by R.D. Carroll: U.S. Geological Survey OpenFile Report [TEI-836], 73 p.

Moore, R.C., Lalicker, C.G., and Fischer, A.G., 1952, Invertebratę Fossils: New York, Mc Graw-Hill Book Company, Inc., 766 p.

Quinlivan, W.D., Sharps, J.A., Ohl, J.P., and Blackmon, P.D., 1985, Lithologic logs of selected exploratory and emplacement drill holes in Areas 9 and 10, Nevada Test Site: U.S. Geological Survey Report USGS-474319 [NTS-265], $66 \mathrm{p}$.

Quinlivan, W.D., Ohl, J.P., and Blackmon, P.D., 1977, Lithologic logs of selected exploratory and emplacement drill holes in Areas 2 and 8, Nevada Test Site: U.S. Geological Survey Report ỰGS-474-227 [NTS-251], $76 \mathrm{p}$.

Rogers, C.L., and Noble, D.C., 1969, Geologic map of the Oàk Spring Butte quadrangle, Nye County, Nevada: U.S. Geological Survey Geologic Quadrangle Map GQ-822, scale 1:24,000.

Russell, C.E., Gillespie, D., Cole, J.C., Drellack, S.L., Prothro, L.B., Thompson, P.H., McCall, R.L., Pawloski, G.A., and Carlson, R., 1996, ER-12-1 Completion Report: Desert Research Institute Water Resources Center Publication No. 45120, DOE/NV/10845-36, 187 p.

Sargent, K.A., Dixon, G.L., and Spengler, R..W., 1972, Lithologic logs and stratigraphic identification of exploratory and emplacement drill holes in Area 7, Nevada Test Site: U.S. Geological Survey Report 474152 [NTS-241], $66 \mathrm{p}$.

Sharps, J.A., 1987, Review of lithologic logs of selected exploratory and emplacement drill holes completed between November 1975. and November 1983 in Area 7, Nevada Test Site, Nye County, Nevada: U.S. Geological Survey Report USGS-474-320 [NTS-266], 137 p. 
Snow, J.K., 1992, Large magnitude Permian shortening and continental-marginal tectonics in the southern Cordillera: Geological Society of America Bulletin, v. 104, p. 80-105.

Trexler, J.H., Jr., and Cashman, P.H., [1997, in press], A southern Antler foredeep submarine-fan: the Mississippian Eleana Formation, Nevada Test Site: Journal of Sedimentary Research, v. xx, p. x-xx.

Trexler, J.H., Jr., Cole, J.C., and Cashman, P.H., 1996, Middle Devonian through Mississippian stratigraphy on and near the Nevada Test Site; implications for hydrocarbon potential: American Association of Petroleum Geologists Bulletin, vol. 80, p. 1736-1762.

United States Department of Energy, 1991, Site specific plan for environmental restoration and waste management, Fiscal years 1992-1996: U.S. Department of Energy, Nevada Operations Office, unnumbered report, $274 \mathrm{p}$.

United States Department of Energy, 1994, United States nuclear tests, July 1945 through September 1992: U.S. Department of Energy, Nevada Operations Office, DOE/NV-209 (rev. 14), 105 p.

United States Geological Survey, 1974, Results of exploration of the Baneberry site, early 1971: U.S. Geological Survey Report USGS-474-145 [NTS-235], 94 p.

Winograd, I.J., and Thordarson, William, 1975, Hydrogeologic and hydrogeochemical framework, south-central Great Basin, Nevada-California, with special reference to the Nevada Test Site: U.S. Geological Survey Professional Paper 712-C, $126 \mathrm{p}$. 
Table 1. Data for selected drillholes that penetrate pre-Tertiary rock in the Yucca Flat area, Nevada Test Site

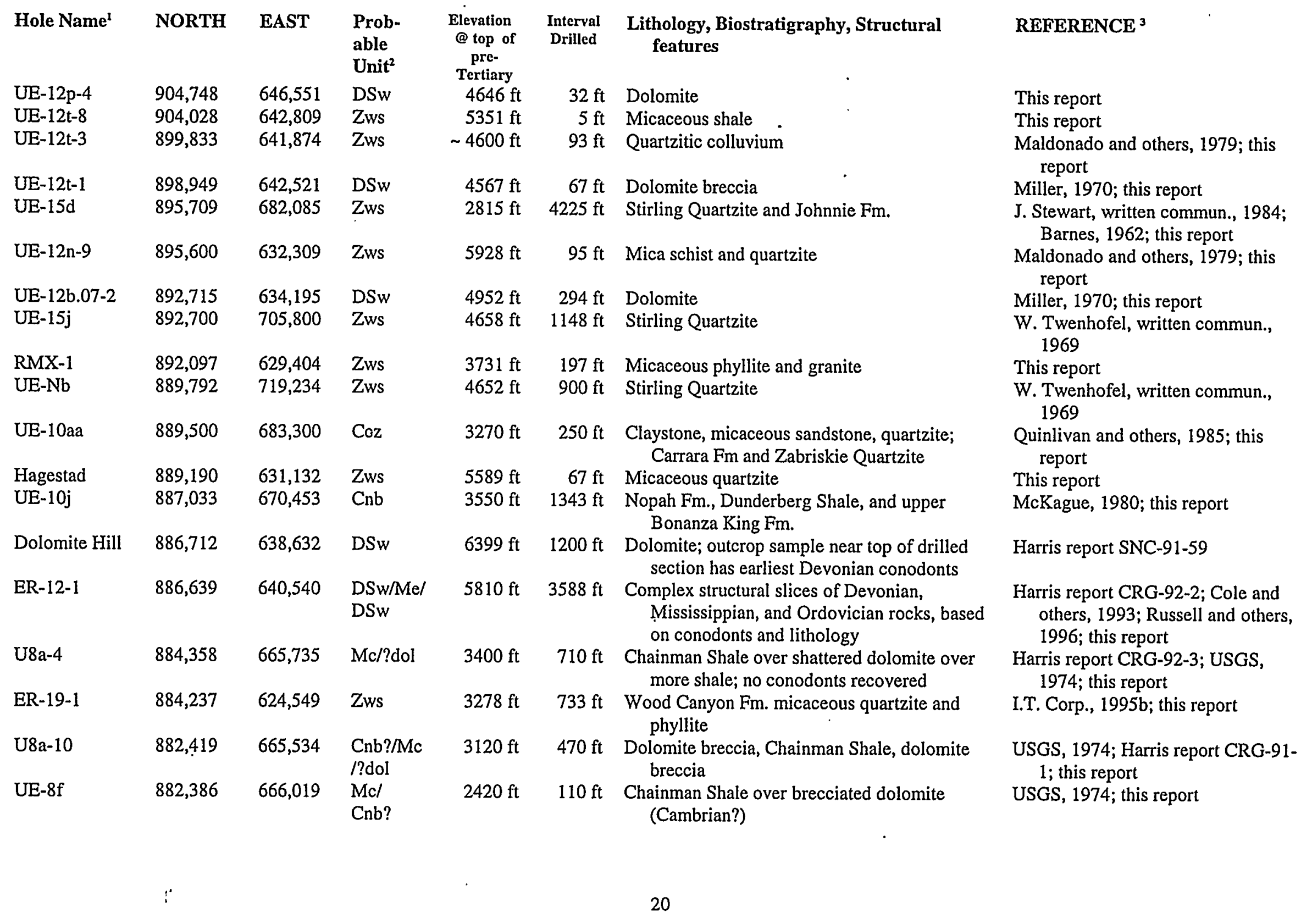


Table 1. Data for selected drillholes that penetrate pre-Tertiary rock in the Yucca Flat area, Nevada Test Site (continued)

\begin{tabular}{|c|c|c|c|c|c|c|c|}
\hline Hole Name ${ }^{1}$ & NORTH & EAST & $\begin{array}{l}\text { Prob- } \\
\text { able } \\
\text { Unit }{ }^{2}\end{array}$ & $\begin{array}{l}\text { Elevation } \\
\text { @ top of } \\
\text { pre- } \\
\text { Tertiary }\end{array}$ & $\begin{array}{c}\text { Interval } \\
\text { Drilled }\end{array}$ & $\begin{array}{l}\text { Lithology, Biostratigraphy, Structural } \\
\text { features }\end{array}$ & REFERENCE $^{3}$ \\
\hline U8a-11 & 881,911 & 665,482 & $\begin{array}{l}\text { Cnb?/ } \\
\text { Mcl } \\
\text { ?dol }\end{array}$ & $2975 \mathrm{ft}$ & $380 \mathrm{ft}$ & $\begin{array}{l}\text { Dolomite breccia, Chainman Shale, dolomite } \\
\text { breccia; high organic carbon content in shale }\end{array}$ & $\begin{array}{l}\text { Carr and others, 1967; USGS, 1974; } \\
\quad \text { Barker, } 1994\end{array}$ \\
\hline U8a-12 & 880,035 & 665,289 & $\begin{array}{l}\text { Cnb?/ } \\
\mathrm{Mcl} \\
\text { ?dol }\end{array}$ & $3285 \mathrm{ft}$ & $405 \mathrm{ft}$ & $\begin{array}{l}\text { Dolomite breccia, Chainman Shale, limestone } \\
\text { and dolomite breccia }\end{array}$ & $\begin{array}{l}\text { Carr and others, 1967; USGS, 1974; } \\
\text { this report }\end{array}$ \\
\hline Water Well 2 & 879,999 & 668,720 & Or & $1921 \mathrm{ft}$ & $872 \mathrm{ft}$ & $\begin{array}{l}\text { Dolomite, fissile limestone and shale, and } \\
\text { dolomite; Early Ordovician trilobites }\end{array}$ & $\begin{array}{l}\text { Moore and others, 1963; Ross report } \\
\text { SP-73-3D }\end{array}$ \\
\hline Test Well 1 & 876,855 & 629,310 & DSw & $2491 \mathrm{ft}$ & $531 \mathrm{ft}$ & Dolomite & This report \\
\hline GH-1 & 873,000 & 662,700 & Cnb? & $4320 \mathrm{ft}$ & $14 \mathrm{ft}$ & $\begin{array}{l}\text { Dolomite and limestone, laminated; beds dip } 15 \\
\text { in core; Bonanza King or Nopah Fm }\end{array}$ & Moore, 1962 ; this report \\
\hline UE-2ab & 873,000 & 666,500 & Cnb? & $3225 \mathrm{ft}$ & $80 \mathrm{ft}$ & Dolomite; no conodonts recovered & Harris report CRG-91-1; this report \\
\hline UE9-ITS-2 & 872,600 & 686,999 & $\begin{array}{l}\text { Cnb- } \\
\text { Or }\end{array}$ & $3788 \mathrm{ft}$ & $42 \mathrm{ft}$ & $\begin{array}{l}\text { Limestone, laminated; Latest Cambrian-earliest } \\
\text { Ordovician conodonts; common phosphatic } \\
\text { brachiopods }\end{array}$ & Harris report CRG-91-1; this report \\
\hline $\mathrm{U} 2 \mathrm{cr}$ & 871,800 & 657,800 & Mc & $3292 \mathrm{ft}$ & $55 \mathrm{ft}$ & $\begin{array}{l}\text { Chainman Shale with crinoids and molds of } \\
\text { woody plant debris }\end{array}$ & This report \\
\hline UE-2ce & 871,700 & 654,900 & $\begin{array}{l}\text { Cnb- } \\
\text { Or }\end{array}$ & $3658 \mathrm{ft}$ & $543 \mathrm{ft}$ & $\begin{array}{l}\text { Dolomite; phosphatic brachiopods; no younger } \\
\text { than Pogonip Group }\end{array}$ & Harris report CRG-91-1; this report \\
\hline UE9-U29-1 & 871,600 & 683,601 & Or & $3110 \mathrm{ft}$ & $110 \mathrm{ft}$ & Limestone; Early Ordovician conodonts & Harris report CRG-91-1 \\
\hline U9-ITS-AA27 & 870,800 & 685,600 & $\begin{array}{l}\text { Cnb- } \\
\text { Or }\end{array}$ & $3665 \mathrm{ft}$ & $60 \mathrm{ft}$ & $\begin{array}{l}\text { Limestone, laminated, silty; phosphatic } \\
\text { brachiopods, Late Cambrian- Early } \\
\text { Ordovician macrofossils }\end{array}$ & Ross report SP-71-1D; this report \\
\hline UE-2u & 870,198 & 653,250 & Cnb? & $3505 \mathrm{ft}$ & $110 \mathrm{ft}$ & Dolomite; no conodonts recovered & Harris report CRG-91-1 \\
\hline UE9-ITS-3 & 869,600 & 684,400 & $\begin{array}{l}\text { Cnb- } \\
\text { Or }\end{array}$ & $3232 \mathrm{ft}$ & $127 \mathrm{ft}$ & Limestone; abundant phosphatic brachiopods & Harris report CRG-91-1; this report \\
\hline UE-2fa-1 & 868,948 & 668,591 & Or? & $1592 \mathrm{ft}$ & $138 \mathrm{ft}$ & Silty limestone; no conodonts recovered & $\begin{array}{l}\text { McKague, 1980; Harris report CRG- } \\
91-1 \text {; this report }\end{array}$ \\
\hline UE9-ITS-1 & 867,602 & 687,350 & Or & $3717 \mathrm{ft}$ & $43 \mathrm{ft}$ & $\begin{array}{l}\text { Laminated limestone; Early Ordovician } \\
\text { conodonts; lower Pogonip Group }\end{array}$ & Harris report CRG-91-1; this report \\
\hline UE-2fb & 865,600 & 669,850 & Or & $1675 \mathrm{ft}$ & $191 \mathrm{ft}$ & $\begin{array}{l}\text { Flaggy limestone and dolomite; Early to middle } \\
\text { Middle Ordovician conodonts }\end{array}$ & Harris report CRG-91-1; this report \\
\hline
\end{tabular}




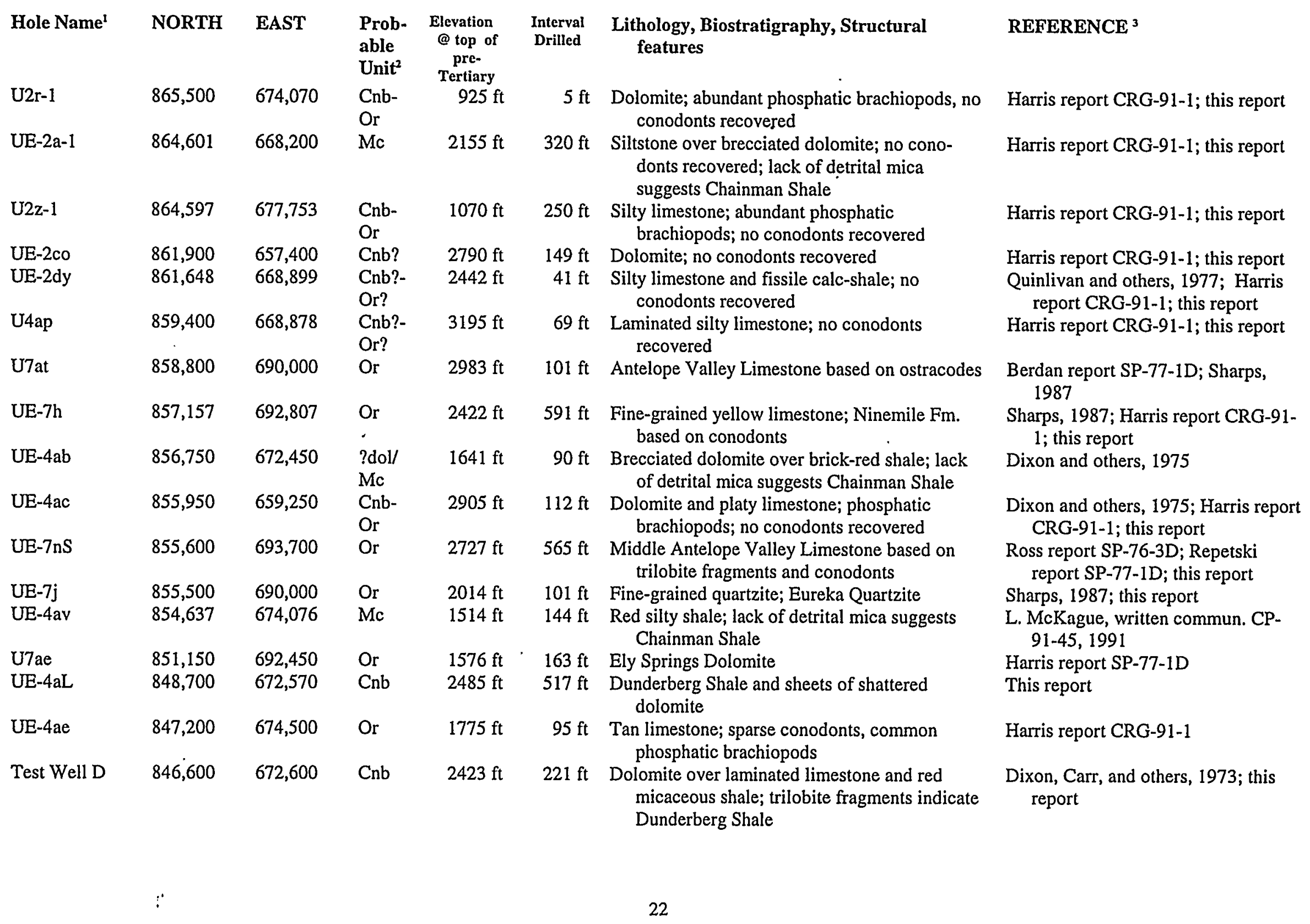


Table 1. Data for selected drillholes that penetrate pre-Tertiary rock in the Yucca Flat area, Nevada Test Site (continued)

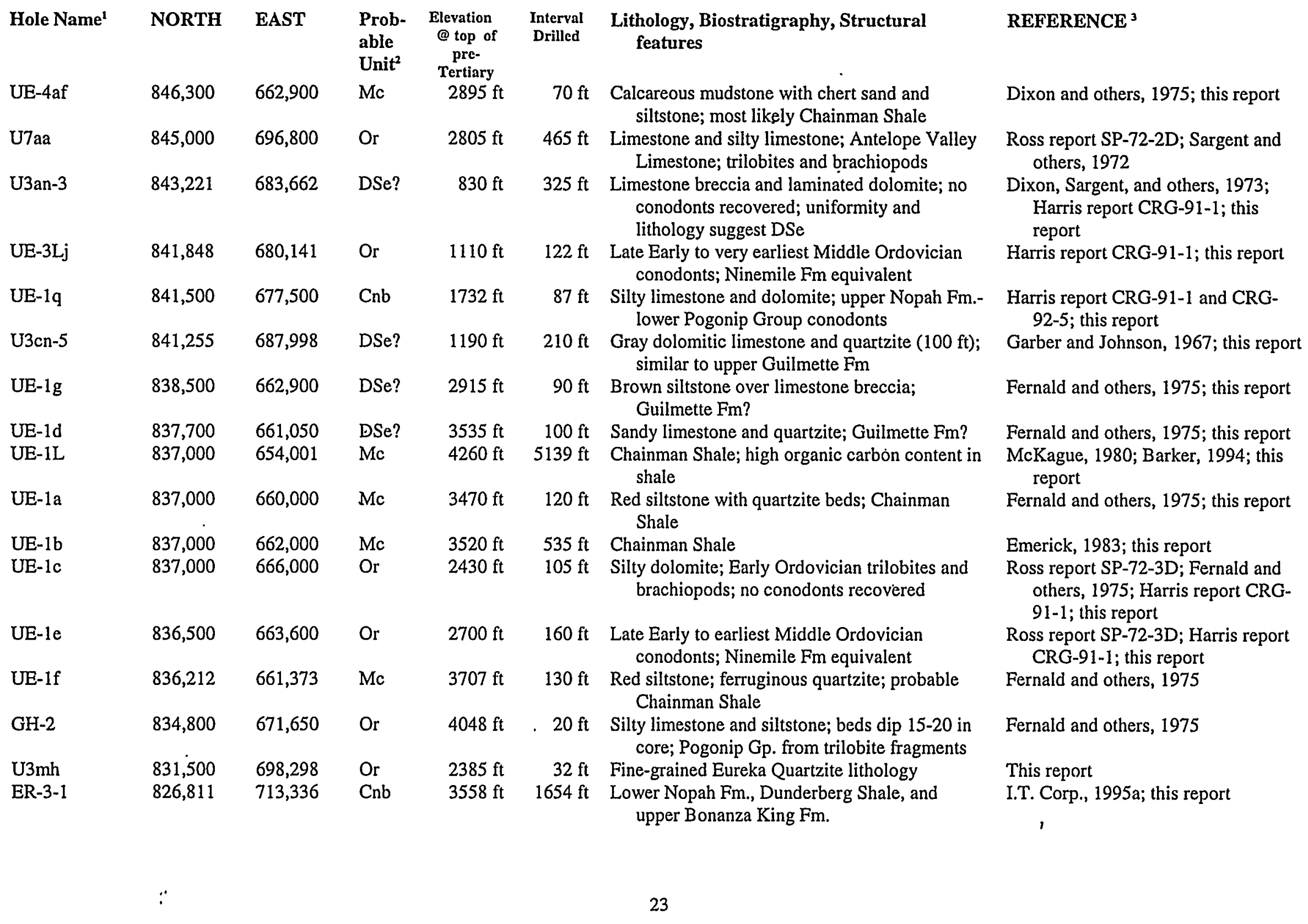


Table 1. Data for selected drillholes that penetrate pre-Tertiary rock in the Yucca Flat area, Nevada Test Site (continued)

\begin{tabular}{|c|c|c|c|c|c|c|c|}
\hline Hole Name ${ }^{l}$ & NORTH & EAST & $\begin{array}{l}\text { Prob- } \\
\text { able } \\
\text { Unit }^{2}\end{array}$ & $\begin{array}{l}\text { Elevation } \\
\text { @ top of } \\
\text { pre- } \\
\text { Tertiary }\end{array}$ & $\begin{array}{l}\text { Interval } \\
\text { Drilled }\end{array}$ & $\begin{array}{l}\text { Lithology, Biostratigraphy, Structural } \\
\text { features }\end{array}$ & REFERENCE ${ }^{3}$ \\
\hline UE-1p & 826,269 & 662,299 & Or & $3459 \mathrm{ft}$ & $9 \mathrm{ft}$ & Eureka Quartzite & This report \\
\hline UE-1m & 825,408 & 657,842 & $\begin{array}{l}\mathrm{Me} / \\
\mathrm{Mc}\end{array}$ & $4478 \mathrm{ft}$ & $514 \mathrm{ft}$ & $\begin{array}{l}\text { Eleana Fm. thrust over Chainman Shale; core } \\
\text { shows conspicuous fault near } 175 \text { foot depth }\end{array}$ & $\begin{array}{l}\text { This report; D. Herring, written } \\
\text { commun., } 1994\end{array}$ \\
\hline UE-1h & 820,000 & 675,000 & Cnb? & $2295 \mathrm{ft}$ & $1658 \mathrm{ft}$ & $\begin{array}{l}\text { Variable gray dolomite; lower part resembles } \\
\text { Banded Mountain Mbr of Bonanza King }\end{array}$ & This report \\
\hline UE-6e & 814,000 & 688,200 & DSe? & (50) $\mathrm{ft}$ & $224 \mathrm{ft}$ & $\begin{array}{l}\text { Dolomitic limestone, quartzitic dolomite; no } \\
\text { conodonts recovered; similar to upper } \\
\text { Guilmette Fm }\end{array}$ & $\begin{array}{l}\text { Fernald and others, } 1975 \text {; Harris } \\
\text { report CRG-91-1; this report }\end{array}$ \\
\hline ER-6-1 & 814,000 & 696,750 & DSe & $2165 \mathrm{ft}$ & $1436 \mathrm{ft}$ & $\begin{array}{l}\text { Lower Sevy Dolomite through upper Eureka } \\
\text { Quartzite based on lithology and conodonts }\end{array}$ & $\begin{array}{l}\text { Harris reports CRG-92-3 and } \\
\text { CNGMT-96-1; this report }\end{array}$ \\
\hline UE-6d-3 & 813,500 & 693,255 & DSe? & $1242 \mathrm{ft}$ & $199 \mathrm{ft}$ & Fossiliferous limestone; Guilmette? Fm. & This report \\
\hline ER-6-2 & 805,312 & 672,493 & $\begin{array}{l}\mathrm{Cnb} / \\
\mathrm{DSe} / \\
\mathrm{Mc}\end{array}$ & $4131 \mathrm{ft}$ & $3329 \mathrm{ft}$ & $\begin{array}{l}\text { Bonanza King thrust on overturned Guilmette } \\
\text { Fm and Chainman Shale (CP thrust) }\end{array}$ & $\begin{array}{l}\text { MicroStrat report MSI 93-22; Harris } \\
\text { report CNGMT-96-1; this report }\end{array}$ \\
\hline Test Well C & 790,082 & 692,061 & DSe & $2566 \mathrm{ft}$ & $346 \mathrm{ft}$ & $\begin{array}{l}\text { Uniform limestone and sandy limestone; beds } \\
\text { dip } 25 \text { in core; probable Guilmette Fm; no } \\
\text { conodonts recovered }\end{array}$ & Harris report CRG-93-2; this report \\
\hline
\end{tabular}

NOTES: All dimensions listed in feet, based on original drilling reports. Divide by 3.28 to convert to meters.

1. Drillholes are listed in order from north to south; Locations are given in Nevada State Plane Coordinates, Central zone (feet)

2. Unit assignment is authors' interpretation based on lithology, biostratigraphic data (if available), and geographic position relative to major thrust sheets and proximity to samples I slash $(/)$ marks indicate multiple units encountered in the hole, listed from top to bottom. Unassigned dolomite breccia indicated by "?dol" where no data for stratigraphic p

3. References listed as (e.g.) "Harris report CRG-91-1" are USGS internal reports by staff paleontologists listing the findings from examinations of fossil collections. These reports 20192. References to "this report" indicate drill core and (or) cuttings examined by Cole. References listed as "MicroStrat report MSI 93-22" are reports of commercial lal Program for the Nevada Test Site. 


\section{NOTICE}

Page(s) size did not permit electronic reproduction. Information may be purchased by the general public from the National Technical Information Service, U.S. Department of Commerce, Springfield, VA 22161 (Area Code 703-487-4650). DOE and DOE contractors may purchase information by contacting DOE's Office of Scientific and Technical Information, P.O. Box 62, Oak Ridge, TN 37831, Attn: Information Services (Area Code 423-576-8401). 